\title{
VIBRATION-BASED DETECTION OF AXIAL-FLOW COMPRESSOR UNSTABLE OPERATION
}

\author{
F. MOHAMMADSADEGHI, V. S. CHYGRYN, S. V. YEPIFANOV
}

\author{
Aircraft Engine Design department of National Aerospace university "Kharkiv Aviation Iinstitute", Kharkiv, UKRAINE \\ e-mail:farrokh_sadeghi@yahoo.com
}

\begin{abstract}
Computer-aided and experimental research of a axial stage stability loss is presented. Informative criteria of the presurge compressor state is formulated. It is proved that the harmonic of a rotating stall is unstable, standing out sharply against noise; thus it can serve as a rotating stall indicator and a surge precursor. It was proved that vibration from the mounted on casing sensor can be applicable for rotating stall detection. An algorithm is proposed that detects the compressor pre-surge state by vibrations of the compressor casing. The algorithm is easy to be implemented in engine control and health monitoring systems Keywords: axial compressor, rotating stall, surge, vibration, median filter, band-pass filter.

\section{СОВЕРШЕНСТВОВАНИЕ МЕТОДОВ ОБНАРУЖЕНИЯ НЕУСТОЙЧИВЫХ РЕЖИМОВ РАБОТЫ ОСЕВЫХ КОМПРЕССОРОВ С ИСПОЛЬЗОВАНИЕМ АНАЛИЗА ВИБРАЦИЙ}

\author{
Ф. МОХАММАДСАДЕГИ, В. С. ЧИГРИН, С. В. ЕПИФАНОВ
}

Кафедра конструкичи авиационных двигателей, Национальный аэрокосмический университет "Харьковский авиационный институт “, Харьков, УКРАИНА

\begin{abstract}
АННОТАЦИЯ Приведены результаты численного моделирования и экспериментальных исследований динамики потери газодинамической устойчивости ступени осевого компрессора. Выполнены исследования по выявлению информативных критериев обнаружения предпомпажного режима. Показано, что гармоника вращающегося срыва является устойчивой, значительно выделяется на фоне шумов, что позволяет использовать ее для диагностики вращающегося срыва как предвестника помпажа. Приведена уточненная зависимость для определения частоты вращающегося срыва. Показано, что для выявления вращающеегося срыва возможно использование параметров вибрации, зарегистрированных на корпусе компрессора. Предложен алгоритм выявления предпомпажного состояния компрессора по уровню вибраций корпуса компрессора для разработки автоматических систем предупреждения помпажа на этапе его зарождения.

Ключевые слова: осевой компрессор, вращающийся срыв, помпаж, вибросигнал, медианная фильтрация, полосовой фильтр
\end{abstract}

\section{Introduction}

An unstable operation of an aircraft engine is among major factors that cause incidents in maintenance. The airflow at the engine inlet can be disturbed by numerous reasons, such as asymmetric incident airflow while the aircraft turning in yaw or pitch, asymmetric incident airflow because of the side wind, atmospheric turbulence, control system malfunction, hot gases entering the engine intake during the taxiing or during formation flying (Fig.1) etc.

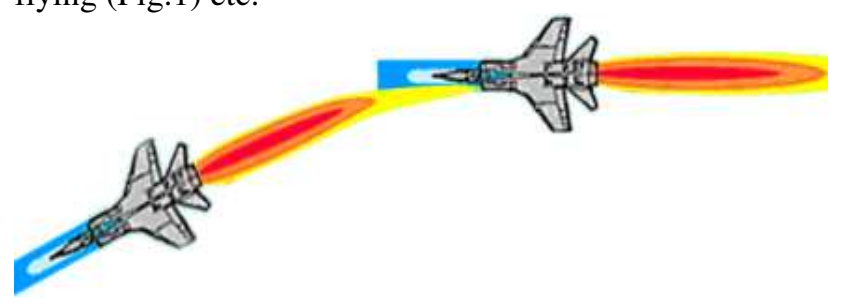

Figure 1 - Hot gas entering the engine intake at the formation flying
When the flow temperature at engine inlet raises, the airflow rate passing through the compressor drops, deforming the velocity triangles at rotor blade inlet thereby. The streamlining at the considered conditions results in rotating stall formation and its propagation in a whole blade wheel up to surge. The surge in compressor of a gas turbine engine is an unstable self-oscillating operation of compressor and its hydraulic network accompanied with an intensive low-frequency $(5 \ldots 15 \mathrm{~Hz})$ parameter oscillations (pressure, temperature, air flow rate) along the entire gas path (Fig. 2).

Surge is an emergent phenomenon that entails compressor blades damaging, turbine blades overheat, a low-frequency oscillations, a rotor axial displacement, seals breakup that causes dynamic stresses in the engine parts, which exceed the design level.

It is known from numerous experiments that the surge temporal progress takes about $0.2 \mathrm{~s}$. Almost all known compressor surge protection algorithms do not prevent the compressor unstable operation but detect the already commenced surge. Therefore, the aircraft power plant has no reliable surge protection. Well-known (c) F. MOHAMMADSADEGHI, V. S. CHYGRYN, S. V. YEPIFANOV, 2016 
methods of stall prevention, such as turning the compressor guide vanes, bypassing the air from intermediate compressor stages, decreasing fuel flow rate to idle value that in their turn significantly decrease the engine thrust or power.

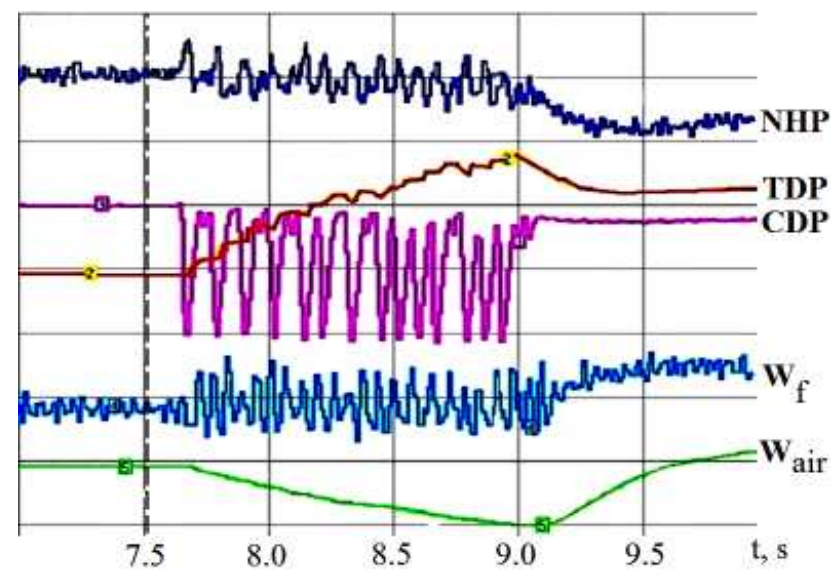

Figure 2 - The generic view of the parameters at a compressor surge: NHP - rotor rotation speed; TDP turbine discharge pressure; $\mathrm{CDP}$ - compressor discharge pressure; $\mathrm{W}_{\mathrm{f}}$ - fuel flow rate; $\mathrm{W}_{\text {air }}$ - air flow rate

The most typical forms of the compressor gasdynamic instability are the rotating stall and the surge. Despite the successes in understanding the problem of the surge and the rotating stall, the development of anti-stall and anti-surge algorithms is still vital.

\section{Problem overview}

Surge is always preceded by the rotating stall. The latest is initiated by a flow disturbance at the compressor inlet or discharge [1]. There are two known mechanisms to explain the surge origination:

- rotating long-wave sinusoidal perturbation of an axial velocity (modal wave);

- local (peak) perturbation that propagates fast from initial local area and envelopes some airfoils.

There are some known strategies worldwide to simulate the surge of axial compressor. Some of them are based on airfoil limit attack angle exceeding [2] or wall boundary layer stall [3], the other ones - on vortex motion of an airflow that leaks through the clearance between blade tip and facing it casing [4] etc. Paper [5] represents the model that describes a consequence of the aerodynamic phenomena that cause the flow instability in a compressor with discontinuous performance. The concept of the "initial vortex area" (IVA) is introduced. According to this model, the boundary layer is separated near the front edge of airfoil at supercritical flow angles. The "air bubble" originates on a suction surface followed by the laminar boundary layer separation near the trailing edge. This fast process of a soft dynamic separation propagates at the relative radius $\bar{r} \approx 0.94 \ldots 0.98$, creating one or some IVA at the periphery. The thickness of the IVA takes 10 percent of the blade length. The rotational speed of the initial areas is close to the rotor rotational speed ( $\bar{n}_{\text {stall }}=n_{\text {stall }} / n_{\text {rot }} \approx 0,97$ ). This process lasts for about $0.1 \mathrm{~s}$ and ends with the formation of the rotating stall. The observer sees periodic oscillations $(0.3 \ldots 0.6$ from the rotor speed). Paper [6] presents similar experimental results for initiated and propagated rotating stall in the axial compressor stage.

Ground and in-flight tests show [7] that the progress of the rotating stall areas is a universal precursor of the surge.

\section{Research tasks}

The primary goal of this research is the development of informative criteria for timely detection of the axial compressor pre-surge state. The secondary goal is to develop an algorithm that implements the developed criteria.

The following tasks must be completed to succeed:

- study and analyze the collected experimental information about non-stationary processes with rapidly-changed parameters in characterstic stages of the axial compressor;

- analyze the methods of a pre-surge diagnostics;

- analyze the sources of a non-stationary signals that influence engine parameters and methods of signal processing;

- choose the informative frequencies;

- select the method and develop the algorithm able to detect an automatic periodic components of a non-stationary oscillations;

-develop informative criteria for a timely detection of the axial compressor pre-surge state;

-develop the surge protection algorithm that implements the above mentioned criteria.

\section{Digital simulation and experimental}

Investigation of the non-stationary processes in the axial compressor stage

The following tasks must be completed for the suitable presentation of the processes that accompany the surge:

-identify the compressor spool, which gasdynamic stability is critical ;

- detect the pre-surge processes, form the informative diagnosing criterions;

- determine the engine control actions that are sufficient to prevent or to stop the surge.

These tasks can be completed experimentally or by digital simulation.

At first stage of the research, we had simulated the airflow in a blade passage of the first compressor stage of turboshaft. The model had been formed as the Reynoldsaveraged Navier-Stockes differential equations 
implemented in ANSYS CFX which is based on the finite-volume method and the implicit algorithm of integration [8]. Flow of the heat-conductive compressible viscous turbulent gas was a subject of the analysis. The above-mentioned software was complemented with the standard tools available in ANSYS.

Simulation showed that the airfoil is regularly streamlined at stable operational modes. When compressor operational mode becomes close to a stability margin, the rotating stall emerges on the convex airfoil surface. The airflow lines dawn everywhere along blade length. Velocity field in the blade passage at prestall conditions on the blade convex side are shown in Fig. 3.

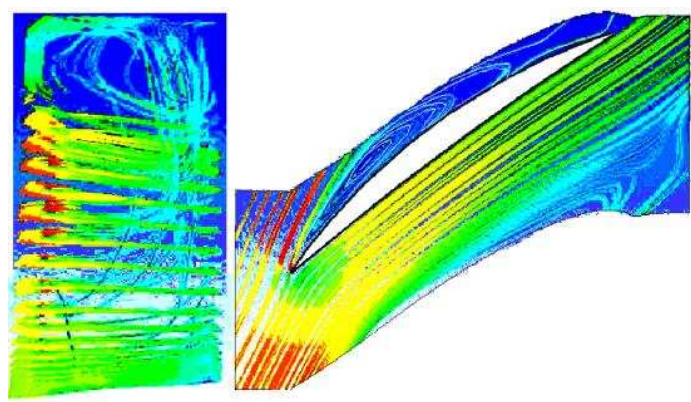

Figure 3 - Stall dawn on the blade convex side

The interblade flow in the axial compressor stage is characterized by the radial equilibrium of flows along the height of the interblade channel. Every cross-section is optimally oriented in the flow at the design operational mode. When the airflow rate abandons the design conditions, different blade cross-sections operate at different off-design conditions.

Stall and surge in compressor have the considerable feature. To be exact, the separate flow areas propagate in blade passages in both, circumferential and longitudinal directions. Then, it is obvious that a blade sector simulation cannot be applied for this case. The above presented considerations prove that the study to be simulated will work with many finite element models. The required evaluations will take long processing time. Therefore, mankind tries its best to develop the reduced models that are able to take the rotating stall features in The following sequence of events must happen to entail the rotating stall, as it is given in [9] (see Fig. 4).

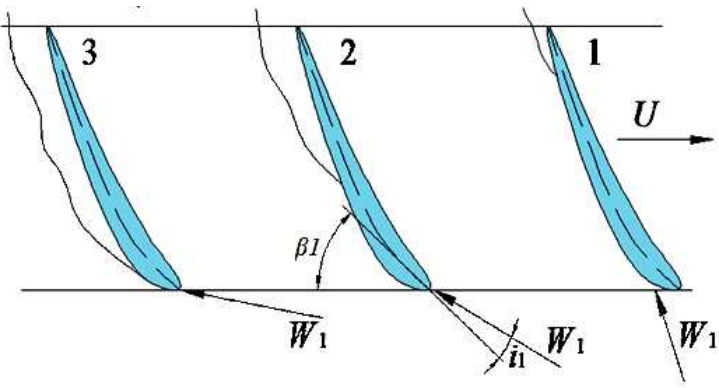

Figure 4 - Rotating stall origination
Under certain conditions attack angles may rise and block part of the interblade channel, reducing its flow capacity (see case 2 in Fig. 4). Flow is forced to be redistributed between adjacent interblade channels. The redistribution happens in the way that the attack angle $i_{I}$ of the blade 1 increases and the attack angle of the blade 3 decreases. Therefore, the stall area moves circumferentially opposite to the hand of rotation at the velocity, which is less than rotation. The flow in annular duct consists of stalled areas and areas of the non-stall flow then. So, in the other words, the rotating stall is a mechanism of compressor "adaptation" to a rapid decreasing of the airflow rate. Instead of uniform circular airflow distribution, the flow is distributed no uniformly. Main portion of the airflow is concentrated in a set of interblade channels and rest airfoil sets operate at partially blocked state. Therefore the averaged in time airflow rate remains constant at the rotating stall operation, but local airflow rate is different in different interblade channels. The areas with stable and unstable operation do not belong to particular blades, because as it was mentioned, stall rotates. One or some of the stalled areas can originate. The stall area can take entire circular cross-section (full-blocking stall) or only some part of it (partial-blocking stall).

These off-design flows initiate the hundreds hertz pressure oscillations [10]. These oscillations cause the radial and axial vibrations of engine casing. Thus, the stall propagation can be detected before the full-scale surge, on a base of a vibration analysis [1].

The results of a simulation had been experimentally validated [11] at the full-scale and laboratory-scale test facilities. Both facilities are of the same structure (Fig. 5).

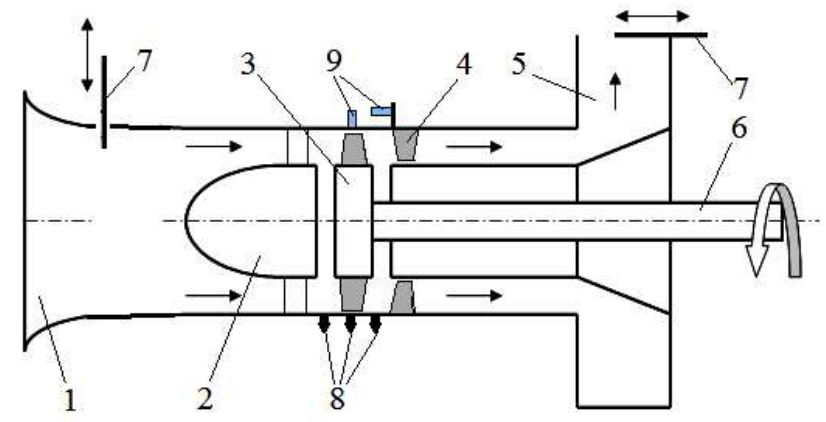

Figure 5 - Scheme of the test facility:

1 - intake; 2 -cowl; 3 -impeller; 4 - guide vanes;

5 -exhaust pipe; 6 -shaft; 7 -throttle; 8 -pressure sensors; 9 - vibration transducers

The full-scale facility is an axial compressor stage (20 blades) with $21 \mathrm{~kW}$ driving electric motor and controlled rotor speed (maximum speed is $3600 \mathrm{rpm}$ ).

The laboratory test facility is a single-stage axial compressor with five rotor blades driven by the electric motor (maximum speed is $2600 \mathrm{rpm}$ ).

The measuring system of the facility includes pressure sensor at the stage inlet (static pressure), pressure 
sensor in the clearance between blades and facing them casing (static pressure), pressure sensor at the stage discharge (static pressure), axial and radial vibration transducers on the engine casing. The pressure fluctuations were recorded by sensors MPX2202, which sensitivity is $0.2 \mathrm{mV} / \mathrm{kPa}$. The length of the pilot-static tube is $L=7.4 \mathrm{~mm}$, the sonic velocity at experimental conditions $\left(20^{\circ} \mathrm{C}\right)$ is $a=343 \mathrm{~m} / \mathrm{s}$. The tube operates like a half-wave resonator. It damps vibrations with wave length $2 L=14.8 \mathrm{~mm}$ and frequency $f=a / 2 \pi L=$ $343 / 2 \cdot 3,14 \cdot 0,0148 \approx 3690 \mathrm{~Hz}$. These vibrations are well over the domain of interest.

The vibrations were recorded by the accelerometer D16, which sensitivity is $1.5 \mathrm{mV} / \mathrm{m} \cdot \mathrm{s}^{2}$ and precise accelerometer $\mathrm{KD}-35$ with sensitivity $4.9 \mathrm{mV} / \mathrm{m} \cdot \mathrm{s}^{2}$.

Vibration sensors were mounted on the compressor casing as along the engine axis as in perpendicular to it. The frequency domain of the sensor studded to the casing is $8 \mathrm{kHz}$ and the sensor magnet to the casing is $4 \mathrm{kHz}$. This satisfies the requirements to the experiment.

Compressor was forced out of stable operational domain to unstable one by a stepless flow throttling at the stage inlet or discharge.

Sensors were connected to a computer that was recording the signals and processed them by the Fast Fourier Transformation (FFT).

The pressure fluctuations recorded by the sensor in the clearance at the flow throttling at laboratory facility inlet are shown in Fig. 6.

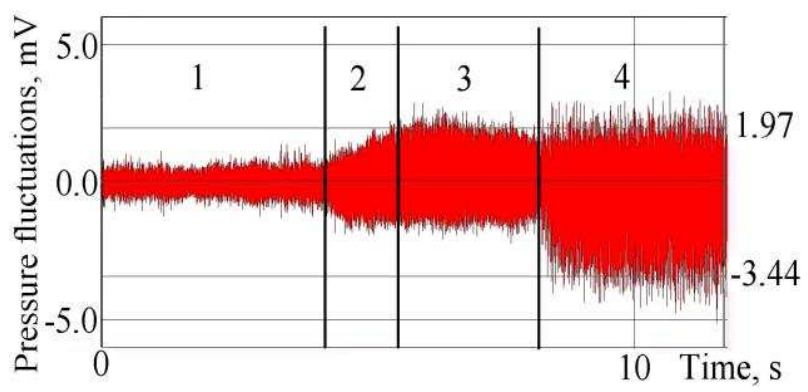

Figure 6-Pressure fluctuations in time domain (sensor in the clearance)

Low-amplitude fluctuations can be recognized in the first section in Fig. 6. The frequency corresponds to blade repetition frequency. When the flow rate decreases then the compressor discharge pressure increases; the system stays stable. Meanwhile conditions of blades streamlining change. This can be understood as a beginning of the stall (sections 2 and 3). Further flow throttling (section 4) makes the flow unstable; pressure at the stage discharge drops and a surge, namely lowfrequency flow pulsations appear. The surge can be recognized by a compressor discharge pressure dips and the ratio of amplitudes $p_{C \max } / p_{C \min } \approx 1.6 \ldots 1.7$. In Fig. 6, this ratio is 1.75 .

Other experiment at the same test facility was made. The stall was stimulated by a periodic short-time supply of the hot air to the inlet. The pressure recorded by the sensor at the impeller discharge is shown in Fig. 7.

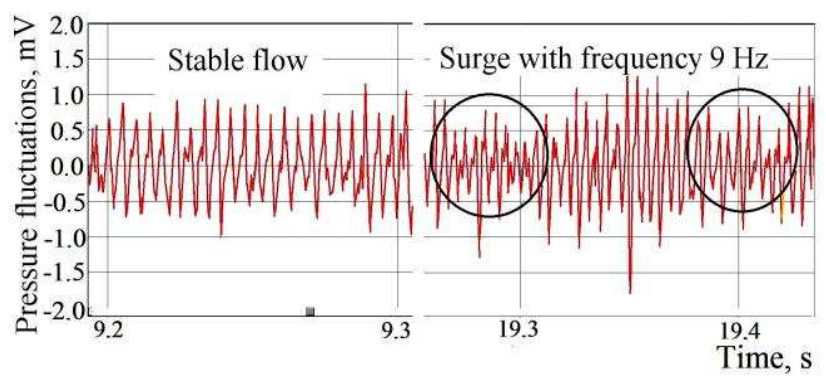

Figure 7 - Pressure fluctuations in time domain (sensor at impeller discharge)

When the stage operates regularly then the pressure pulsates with almost constant amplitude. The frequency is equal to a blade repetition frequency. When hot air gets to the duct, the fluctuation amplitude changes (increases/decreases) for short periods of time; the frequency is $9 \mathrm{~Hz}$ that corresponds to the surge. Herewith, the surge margin decreasing is accompanied with the amplitude of the blade oscillation higher harmonic (from 2-nd to 5-th) increasing for $6 \ldots 9 \mathrm{~dB}$ in respect to the first harmonic. These data shown in Fig. 8 prove the investigation results [12].

The firsts to detect the beginning of the stall were sensors fitted in the clearance (above the blades). The sensors at the impeller discharge discover the formed stall and the sensors at the inlet discover only the progressing surge.

When the throttle ratio increases, the frequencies, equal or proportional to blade repetition frequency also increase (see Fig. 8).

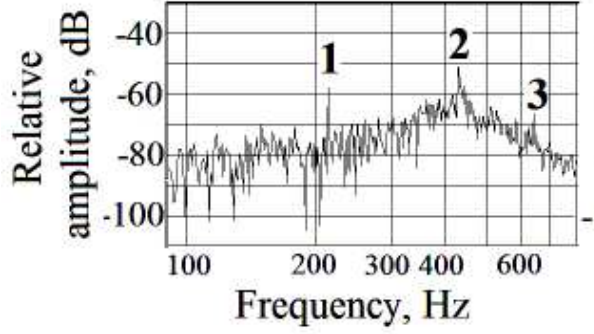

$a$

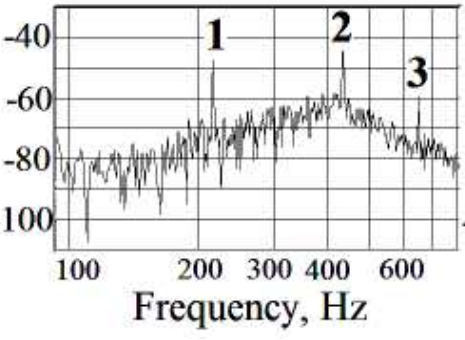

$b$

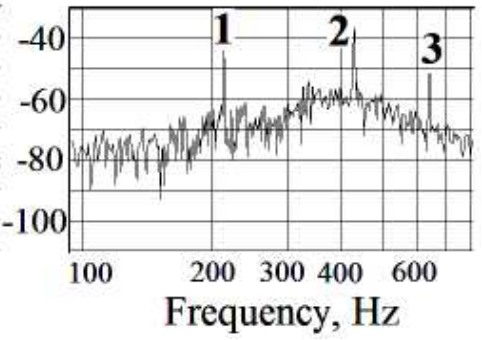

$c$

Figure 8-Spectrogram of the pressure fluctuations: $a$-stable operation; $b$ - stalled flow; $c$-surge 
Therefore this phenomenon can be used as the stall or surge indicator. But, this can be applied to a low speed compressor. For example, the first dry-bending critical speed of forty-blade impeller, which rotational speed is $18000 \mathrm{rpm}$ is $12 \mathrm{kHz}$; so the right margin of the sensor band must be $25 \mathrm{kHz}$ as minimum. Besides, the pressure pipelines must operate in wide band without damping [13] or blocking.

The rotating stall appears at off-design operating conditions and is characterized with the local pressure drop in one or some areas of the compressor gas path (Fig. 9). This causes the stalled streamlining of the rotor blades. The rotating stall initiates low-frequency axial and radial vibrations of the compressor casing. The stall rotates at speed about $(0.3 \ldots 0.6) \cdot n_{\text {rot }}$ depending on the number of rotor blades, the number of guide vanes and the relative bush diameter.
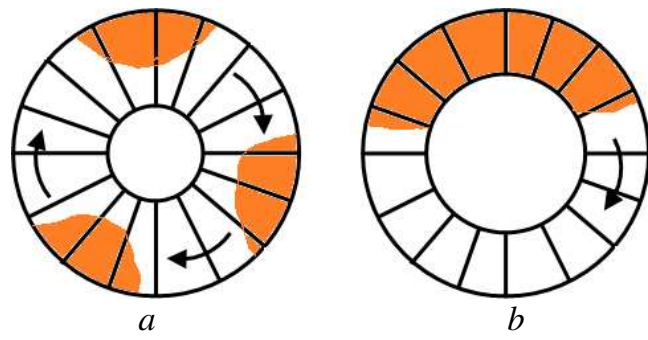

Figure 9 - Various types of the rotating stall: $a$ - partial-blocking stall (three stall areas); $b$-full-blocking stall

The detection of the vibration like just considered means that the surge is very probable to appear in compressor. Thus, the presented above details about the progressing stall and surge prove that progressing stall can be stopped prior it transforms to the full-scale surge.

According to the full-scale experiments, (see Fig. 10) the common level of a broad-band vibration changes insignificantly at the rotating stall. So, this signal cannot serve for a pre-surge diagnostics. The rotational speed was noted to grow incidentally at throttling. This growth happens because of two reasons, which are an unloading of the driving electric motor and a reduction of the airflow rate.

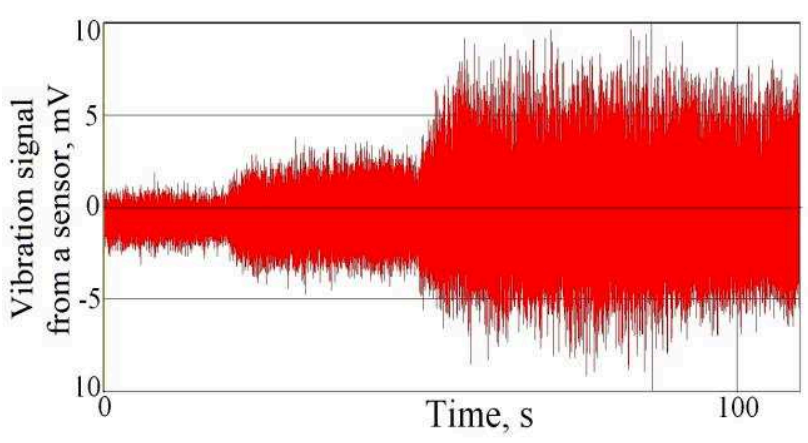

Figure 10 -Vibration recorded by the sensor on the casing of the full-scale compressor stage
The paper [14] represents a method of the rotating stall frequency determination. The relative rotating stall frequency $\bar{n}_{\text {stall }}=n_{\text {stall }} / n_{\text {rot }}$ is determined as a function of the relative bush diameter $\bar{d}$ by the experimental formula. We have refined this function using obtained experimental data:

$$
\bar{n}_{\text {stall }}=\left(0,32773+0,97254 \bar{d}-1,2295 \bar{d}^{2}\right) \pm 0,04239 .
$$

This function is shown in Fig. 11. It was evaluated by the processing of the experimental data. The proposed formula suits the range of the relative rotational speed $\bar{n}=0.3 \ldots 1.0$.

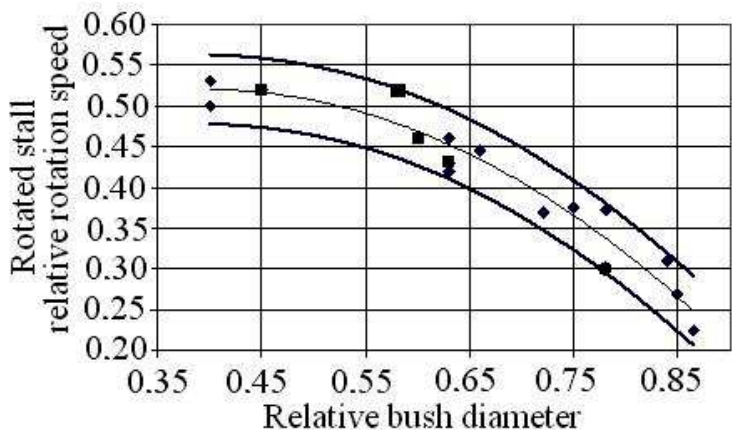

Figure 11 - Dependence of the stall rotational speed on the relative bush diameter: - by paper [14];

- - by paper [6]; - -determined by the authors

Vibrations detected by the sensor mounted on the compressor casing depends on the load acting a radial thrust bearing of the rotor. This problem was not investigated in the presented research, nevertheless signal from both sensors can be considered informative. A spectrum of rotating stall vibration in the range of rotor frequencies in shown in Fig. 12. This spectrum is determined as a decomposition of the precise accelerometer KD-35 signal, mounted perpendicularly to the compressor axis.

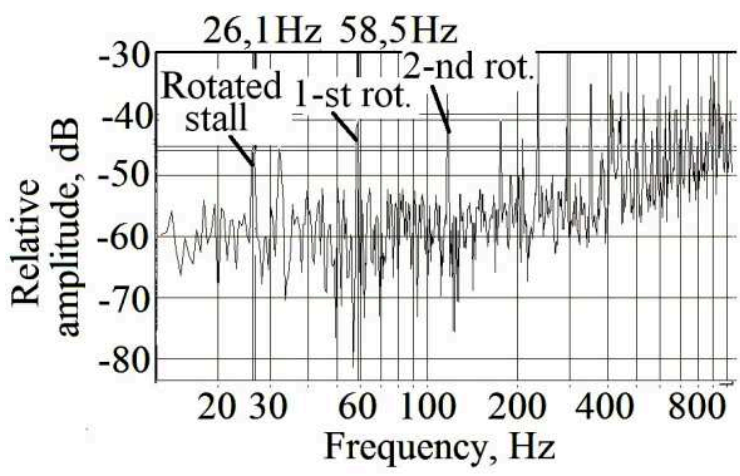

Figure 12 - Vibration spectrum at the rotating stall

The relative bush diameter of the experimental facility is $\bar{d}=0.63$, so the design frequency of the rotating stall with single stalled area is $(0.4524 \pm 0.042) n_{\text {rot }}=26.48 \mathrm{rps}$. This value satisfactorily 
conforms to the experimentally determined value of stall harmonic, which is $26.1 \mathrm{~Hz}$ (the relative error is $1.46 \%$ ).

The stall harmonic is stable. It significantly rises above the noise background (it is $11 \mathrm{~dB}$ above the noise in the experiment). Therefore it is suitable for the rotating stall diagnostics.

\section{Algorithm of the compressor pre-surge state diagnostics}

The recorded signal typically consists of a wanted signal $s\left(t-\tau_{0}\right)$, a fluctuation noise $q(t)$ and an impulse noise $g(t)=\Sigma_{k} s\left(t-\tau_{k}\right)$ :

$$
x(t)=s\left(t-\tau_{0}\right)+q(t)+g(t) .
$$

These components are of different intensity and structure.

The impulse noise is a signal distortion by an intensive short-time random-polarity impulse overshoots. The impulse noise may emerge because of external burst electromagnetic interferences or interference jamming, bugs and interference in the system itself. A combination of a random noise and the quasi-determined impulses is the combined interference. The noise-immune data processing is the most effective method for the combined interference suppression. However, the implementation of the considered data processing method slows data processing down and complicates a data processing system. The task is to filter random components off from the signal, saving the harmonic components. There is no known mathematically rigorous problem formalization of the impulse noise signal filtering problem and its solution. Only heuristic algorithms suite to find the solution of the considered filtering problem. The most appropriate among them is a median filtering algorithm [15].

The median filter is the nonlinear digital filter that member-by-member slides by the signal array and after each iteration returns one of members, which had entered the filter band (aperture). The output signal $y_{k}$ of the $2 n+1$ band sliding median filter at current instant $k$ is formed from the input time series ..., $x_{k-1}, x_{k}, x_{k+1}, \ldots$ as

$$
y_{k}=\operatorname{med}\left(x_{k-n}, x_{k-n+1}, \ldots, x_{k-1}, x_{k}, x_{k+1}, \ldots, x_{k+n-1}, x_{k+n}\right),
$$

where $\operatorname{med}\left(x_{1}, \ldots, x_{m}, \ldots, x_{2 n+1}\right)=x_{m}$ is the median member of the time series ranked on ascending or descending.

The specific feature of a median filter is the explicit selectivity to the elements of an array that are considerably different from adjacent elements. Simultaneously, the median filter does not change a monotone component. Due to this feature, the median filters with optimally adjusted aperture are efficient in the pattern recognition. For example, they can save sharp edges of the objects and effectively suppress the noncorrelated or low correlated noise and low-size details. Therefore, the median filtering is an efficient processing tool that filters abnormal values off data arrays, decreases influence of overshoots and the impulse noise.

Signals detected by fast-response transducers usually contain non-harmonic peak-like (stall) components. Nowadays the secondary processing of such signals is made using the Wavelet transformation. But, the processing in this case needs much processing time. For example, the paper [1] gives comparison of the processing time required to identify the rotating stall using the FFT and the Wavelet-transformation. The FFT required time is up to 40 rotor revolutions, and the Wavelettransformation required time is 400 revolutions. So if the rotational speed is $12000 \ldots 18000 \mathrm{rpm}$ then FFT needs $0.13 \ldots 0.2 \mathrm{~s}$ (this time is commensurable to a surge progress time), and the Wavelet-transformation needs $1.3 \ldots 1.4 \mathrm{~s}$ (the simplest Haar wavelet needs $0.4 \mathrm{~s}$ ), which is unacceptable because gives no chances to detect the surge.

The mentioned above data can be processed using an adaptive band filter [16], which frequency burst is adjusted on a pilot signal from a rotor speed induction sensor. The processing time is about $0.1 \mathrm{~s}$ then. ACS gains an opportunity to form on-time counteraction before the surge origination and progression.

The software of vibration signal processing was developed. It has the following performances. The time to read and process one observation with $2.4 \mathrm{GHz}$ Intel CPU takes $1,15 \cdot 10^{-4} \mathrm{~s}$. The time interval between signal recording and processing is $0.014 \mathrm{~s}$ at $512 \mathrm{~Hz}$ recording and the median filter usage with "three points" aperture and seven-point processing by the band Butterworth filter [17]. This provides reliable rotating stall detection. The analysis of compressor casing vibrations using the median filter and the band filter (mean frequency $26.48 \mathrm{~Hz}$ and bandwidth $\pm 2 \mathrm{~Hz}$ ) is shown in Fig. 13 (upper diagram - in a time domain, down diagram - in a frequency domain).

It is obvious that the vibration signal at a developed rotating stall is twice more than a signal at stable operation (see Fig. 13). So, it can be the criterion of the compressor pre-stall state. When the surge progresses, the rotating stall disappears and the low-frequency component $(9.8 \mathrm{~Hz})$ appears that authenticates the surge. The reason for a signal rise after a surge had developed is a throttling rate decreasing.

Thus, the compressor pre-surge detection algorithm consists of:

- the rotor rotational speed measurement by a standard sensor with $5 \mathrm{~Hz}$ sampling frequency and the pilot signal formation;

- the compressor casing vibration recording with frequency that is no less than the rotor rotational frequency;

- the rotating stall frequency calculation and the filter pass band determination;

- the band filter formation;

- the signal median filtering;

- the processed signal band filtering, the signal rate determination;

- the surge signal formation and control action generation. 


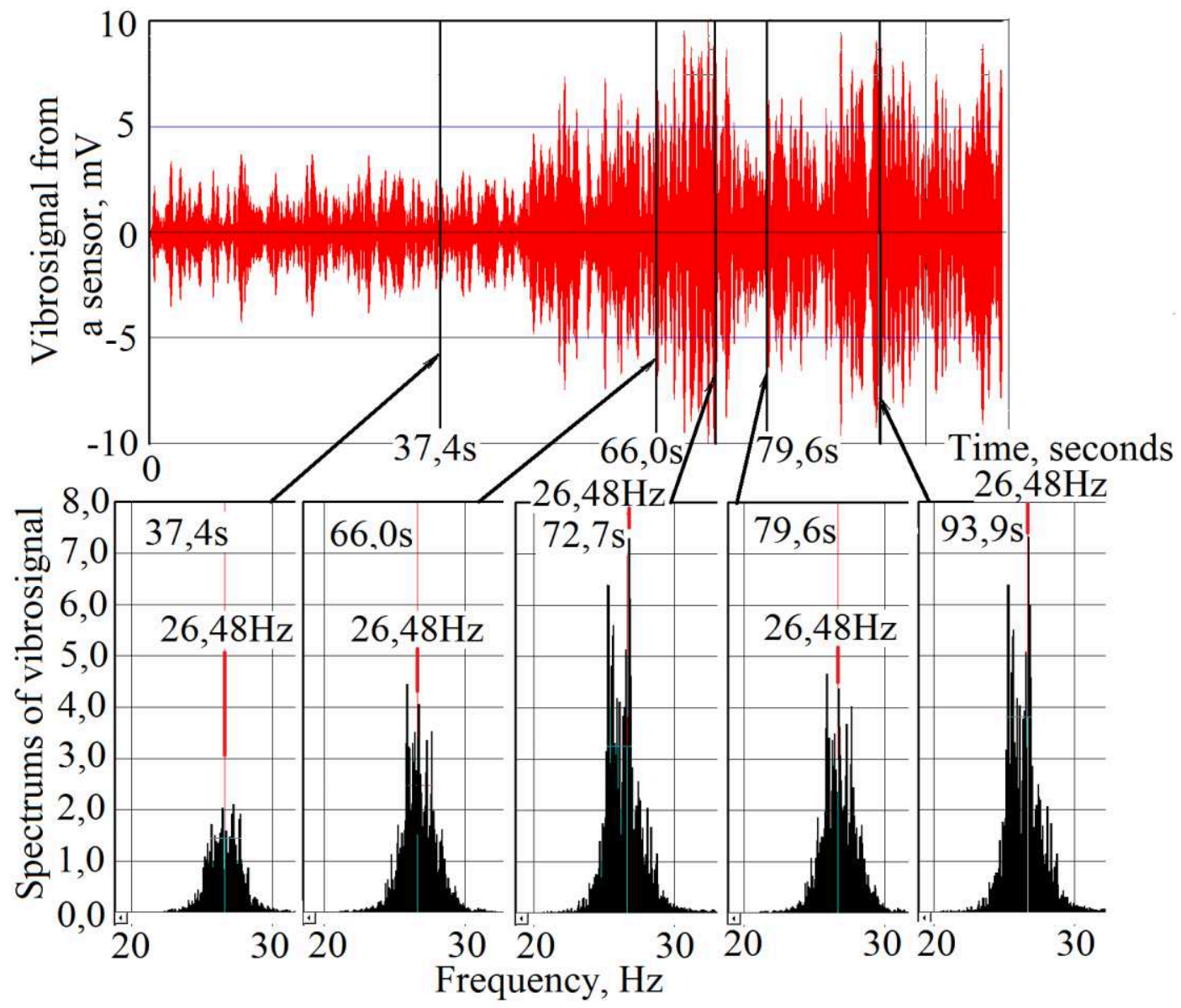

Figure 13 - Vibration signal after median and band filtering

Surge protection system may become much reliable whether it simultaneously processes the signals from several sources of information, like spectral components of the compressor casing vibration. The just mentioned arrangements may improve the engine maintainability. The incoming signal from one source approves or does not approve the signal from the other source. The signals are of different nature. Such signal analysis reduces the risk of false response and improves the reliability of the surge detection system.

\section{Conclusion}

Known surge protection systems snap into action at the developed surge. However, a surge predecessor, rotating stall, appears well prior to a surge, feeding the automatic surge protection system with information. Besides general level of pressure fluctuations, several spectral components can be separated that indicate origination and development of the rotating stall.

The coefficients in the formula relating rotating stall frequency with relative bush diameter of compressor had been refined from the experimental data. Increase in vibration level at this frequency can indicate that the compressor is at the pre-surge state. The algorithm, which automatically recognizes periodic components of the compressor casing vibrations and forms the control actions for the surge protection was proposed.

Surge protection system may become much reliable whether it simultaneously processes the signals from several sources of information, like spectral components of the compressor casing vibration. The just mentioned arrangements may improve the engine maintainability. The incoming signal from one source approves or does not approve the signal from the other source. The signals are of different nature. Such signal analysis reduces the risk of false response and improves the reliability of the surge detection system.

Existing anti-surge systems of gas turbine engine are included into operation at surge increase though preceding rotating stall commences much earlier and can serve as informational criterion for its inclusion into system of engine automatics. Except general level of pressure fluctuations and vibrations, it is possible to single out several spectral components reacting to origination and increase of rotating stall resulting in surge.

It is proved that the reliability of the surge protection system can be improved by more full usage of GTE capabilities, like checking up the signal from one source by the signal from the other source. The signals are of different nature. 


\section{Список литературы}

1. Августинович, В. Г. Численное моделирование нестационарных явлений в газотурбинных двигателях / В. Г. Августинович, Ю. Н. Шмотин, А. П. Сипатов и др. - М. : Машиностроение. - 2005. - 536 с.

2. Hah, C. Characteristics of tip clearance flow instability in a transonic compressor / C. Hah, M. Voges, M. Mueller, H.P. Schiffer // Proc. Of ASME Turbo Expo: GT201020101, 14-18 June 2010. - Glasgow, UK. - 2010. - 12 p. doi:10.1115/GT2010-22101.

3. Greitzer, E. M. Surge and rotating stall in axial flow compressors, PartII: Experimental results and comparison with theory / E.M. Greitzer // Journal of Engineering for Power 98. - 1976. - P. 199-217.

4. Коваль, В. А. Прогнозирование режимов вращающегося срыва в ступени осевого компрессора с учетом формирования профильного и торцевого пограничных слоев / В. А. Коваль, Е. А. Ковалева // Современные технологии в газотурбостроении: -2010. - № 3/3(45). - С. 4-8.

5. Колесинский, Л. Д. Исследование процессов развития вращающегося срыва в осевом компрессоре после нарушения газодинамической устойчивости / Л. Д. Колесинский // Ученые записки ЦАГИ, т. 39. - 2008. № 1 - 2. - С. 92-98.

6. Mathioudakis, K. Flow in the three-dimensional areas of the developed derangement in an axial compressor / $\mathbf{K}$. Mathioudakis, F. A. E. Breugelmans // Journal of Propulsion and Power. - 1988. - №. 3. - P. 263-269.

7. Колесинский, Л. Д. Анализ протекания нестационарных явлений в многоступенчатом осевом компрессоре, работающем в системе стенда, при помпаже / Л. Д. Колесинский, О. В. Макашева // Ученые записки ЦАГИ, т. 39. - 2008. - № 4. - С. 46-59.

8. Menter, F. R. Two-Equation Eddy-Viscosity Turbulence Models for Engineering Applications / F. R. Menter // AIAA Journal. - 1994. - Vol. 32, Issue 8. - P. 1598-1605. doi:10.2514/3.12149.

9. Кампсти, Н. Аэродинамика компрессоров: пер. с англ / Н. Камсти. - М.: Мир. $-2000 .-688$ с.

10. Киприч, Т. В. Исследование методов и моделей обнаружения помпажных явлений в системе автоматического управления ГТД / Т. В. Киприч, В. Н. Харитонов, В. И. Дубровин // Авиачионнокосмическая техника и технология. - 2008. - № 9(56). - C. 206-210.

11. Мохаммадсадеги, Ф. Моделирование срывных и неустойчивых режимов работы ступени осевого компрессора для диагностики его предпомпажного состояния / Ф. Мохаммадсадеги // Вестник двигателестроения. Научно-технический журнал. Запорожье, АО «Мотор Сич». - 2014. - №2. - С. 80-83.

12. Варжицкий, Л. А. Исследование спектральной модели пульсаций давления в осевом компрессоре для диагностики газодинамической неустойчивости / Л. А. Варжицкий, Ю. В. Киселев, М. К. Сидоренко // Вибрационная прочность и надежность двигателей и систем летательных аппаратов. Сборник научных трудов. - Куйбышев: КУАИ. - 1988. - С. 20-24.

13. Шорин, В. П. Акустические методы и средства измерения пульсаций давления / В. П. Шорин, Е. В. Шахматов, А. Г. Гимадиев и др. - Самара: СГАУ. 2007. -132 c.

14. Колесинский, Л. Д. Определение вращающегося срыва в осевом многоступенчатом компрессоре ГТД / Л. Д.
Колесинский, О. В. Макашева // Полет. - 2010. № 3. - C. 36-41.

15. Hung, M. H. A Fast Algorithm of Temporal Median Filter for Background Subtraction / M. H. Hung, J. S. Pan, C. H. Hsieh // Journal of Information Hiding and Multimedia Signal Processing. - 2014. - Vol. 5, №. 1. - P. 33-40.

16. Чигрин, В. С. Віброакустика i вібродіагностика авіаційних двигунів: навч. посіб / В. С. Чигрин, С. І. Суховій. - X.: Національний аерокосмічний університетт «XAI». - 2012. - $264 \mathrm{c}$.

17. Ifeachor, E. C. Digital Signal Processing: A Practical Approach (2nd Edition) / E.C. Ifeachor, B.W. Jervis. Prentice Hall. - 2002. - 934 p.

\section{Bibliography (transliterated)}

1. Avgustinovich, V. G., Shmotin, Yu. N., Sipatov, A. P. i dr. Chislennoe modelirovanie nestatsionarnyih yavleniy $\mathrm{v}$ gazoturbinnyih dvigatelyah [Numerical simulation of transient phenomena in gas turbine engines]. Moskov: Mashinostroenie, 2005, $536 \mathrm{p}$.

2. Hah, C., Voges, M., Mueller, M., Schiffer, H.P. Characteristics of tip clearance flow instability in a transonic compressor. Proc. Of ASME Turbo Expo: GT2010-20101, Glasgow, 2010, 12 p. doi:10.1115/GT2010-22101.

3. Greitzer, E. M. Surge and rotating stall in axial flow compressors, PartII: Experimental results and comparison with theory. Journal of Engineering for Power 98, 1976, 199-217.

4. Koval, V. A., Kovaleva, E. A. Prognozirovanie rezhimov vraschayuschegosya sryiva $\mathrm{v}$ stupeni osevogo kompressora $\mathrm{s}$ uchetom formirovaniya profilnogo $\mathrm{i}$ tortsevogo pogranichnyih sloev [Prediction rotating stall regimes stage axial compressor based on the formation of the profile and mechanical boundary layers]. Sovremennyie tehnologii $v$ gazoturbostroenii [Modern technologies in gas turbine manufacture], 2010, 3/3(45), 4-8.

5. Kolesinskiy, L. D. Issledovanie protsessov razvitiya vraschayuschegosya sryi-va $\mathrm{v}$ osevom kompressore posle narusheniya gazodinamicheskoy ustoychivosti [Investigation of the processes of rotating stall in axial compressor after violation dynamic stability]. Uchenyie zapiski TsAGI, 39 [TsAGI scientists note, v. 39], 2008, 1 - 2, 92-98.

6. Mathioudakis, K., Breugelmans, F. A. E. Flow in the three-dimensional areas of the developed derangement in an axial compressor. Journal of Propulsion and Power, 1988, 3, 263-269.

7. Kolesinskiy, L. D., Makasheva, O. V. Analiz protekaniya nestatsionarnyih yavleniy $\mathrm{v}$ mnogo-stupenchatom osevom kompressore, rabotayuschem $\mathrm{v}$ sisteme stenda, pri pompazhe [Analysis of transient flow phenomena in a multistage axial compressor system operating in the stand, when the surge]. Uchenyie zapiski TsAGI, 39 [TsAGI scientists note, v. 39], 2008, 4, 46-59.

8. Menter, F. R. Two-Equation Eddy-Viscosity Turbulence Models for Engineering Applications. AIAA Journal, 1994, 32(8), 1598-1605, doi:10.2514/3.12149.

9. Kampsti, N. (2000). Aerodinamika kompressorov: per. s angl [Aerodynamics compressors: Trans. with English]. Moskov: Mir, $688 \mathrm{p}$.

10. Kiprich, T. V., Haritonov, V. N., Dubrovin, V. I. Issledovanie metodov i modeley obnaruzheniya pompazhnyh yavleniy $\mathrm{v}$ sisteme avtomaticheskogo upravleniya GTD [Research methods and models of surge 
effects detecting in the GTE automatic control system] Aviatsionno-kosmicheskaya tehnika $i$ tehnologiya [Aerospace Engineering and Technology], 2008, 9(56), 206-210.

11. Mohammadsadegi, F. Modelirovanie sryvnyh i neustoychivyh rezhimov rabotyi stupeni osevogo kompressora dlya diagnostiki ego predpompazhnogo sostoyaniya [Modeling teams and unstable modes of the axial compressor stages to diagnose his condition predpompazhnogo]. Vestnik dvigatelestroeniya. Nauchnotehnicheskiy zhurnal [Bulletin engine. Scientific and technical journal], Zaporozhe, AO «Motor Sich», 2014, 2. 80-83.

12. Varzhitskiy, L. A., Kiselev, Yu. V., Sidorenko, M. K. Issledovanie spektralnoy modeli pulsatsiy davleniya $\mathrm{v}$ osevom kompressore dlya diagnostiki gazodinamicheskoy neustoychivosti. Vibratsionnaya prochnost i nadezhnost dvigateley i sistem letatelnyih apparatov [Study of the spectral model of pressure fluctuations in the axial compressor for the diagnosis of gas-dynamic instability]. Vibratsionnaya prochnost' $i$ nadezhnost' dvigateley $i$ sistem letatel'nykh apparatov. Sbornik nauchnykh trudov [Vibration resistance and reliability of engines and aircraft systems. Collection of scientific papers], Kuybyishev: KUAI, 1988, 20-24.

13. Shorin, V. P., Shahmatov, E. V., Gimadiev, A. G. i dr. Akusticheskie metodyi i sredstva izmereniya pulsatsiy davleniya [Acoustic methods and means of measuring pressure pulsations]. Samara: SGAU, $132 \mathrm{p}$.

14. Kolesinskiy, L. D., Makasheva, O. V. Opredelenie vraschayuschegosya sryiva $\mathrm{v}$ osevom mnogostupenchatom kompressore GTD [Determination of rotating stall in axial multistage compressor GTE]. Polet, 2010, 3, 36-41.

15. Hung, M. H., Pan, J. S., Hsieh, C. H. A Fast Algorithm of Temporal Median Filter for Background Subtraction. Journal of Information Hiding and Multimedia Signal Processing, 2014, 5(1), 33-40.

16. Chygryn, V. S., Suhoviy, S. I. Vibroakustyka i vibrodiagnostyka aviatsyinyh dvyguniv: navch. posib [Vibroakustyka Lathe vibration monitoring and aircraft engines: teach. guidances]. Natsional'niy aerokosmichniy universitett «KhAI» [National Aerospace University "KhAI"], 2012, $264 \mathrm{p}$.

17. Ifeachor, E. C., Jervis, B. W. Digital Signal Processing: A Practical Approach (2nd Edition). Prentice Hall, 2012, $934 \mathrm{p}$.

\section{About authors (Сведения об авторах)}

Mohammadsadeghi Farrokh - post-graduate student of Aircraft Engines Design department of National Aerospace University "Kharkiv Aviation Institute", Kharkiv, Ukraine, e-mail: farrokh_sadeghi@yahoo.com

Мохаммадсадеги Фаррох - аспирант кафедры конструкции авиационных двигателей Национального аэрокосмического университета «Харьковский авиационный институт», Харьков, Украина, е-таil: farrokh_sadeghi@yahoo.com

Chygryn Valentyn - candidate of technical science, associate professor of Aircraft Engine Design department of National Aerospace university "Kharkiv Aviation institute“, Kharkiv, Ukraine, e-mail: chigrin_vs@ rambler.ru

Чигрин Валентин Семенович - кандидат технических наук, доцент кафедры конструкции авиационных двигателей Национального аэрокосмического университета «Харьковский авиационный институт», Харьков, Украина, е-таil: chigrin_vs@rambler.ru

Yepifanov Sergiy - doctor of technical sciences, professor, Honored worker of science of Ukraine, Head of Engine Design department of National Aerospace university "Kharkiv Aviation institute“, Kharkiv, Ukraine, e-mail: aedlab@gmail.com

Епифанов Сергей Валерьевич - профессор, доктор технических наук, заслуженный деятель науки и техники Украины, заведующий кафедрой конструкции авиационных двигателей Национального аэрокосмического университета «Харьковский авиационный институт», Харьков, Украина, e-mail: aedlab@gmail.com

Please cite this article as:

Mohammadsadeghi, F., Chygryn, V., Yepifanov, S. Vibration-based detection of axial-flow compressor unstable operation. Bulletin of NTU "KhPI". Series: New solutions in modern technologies. - Kharkiv: NTU "KhPI", 2016, 12 (1184), 62-70, doi:10.20998/2413-4295.2016.12.09.

Пожалуйста ссылайтесь на эту статью следующим образом:

Мохаммадсадеги, Ф. Совершенствование методов обнаружения неустойчивых режимов работы осевых компрессоров с использованием анализа вибраций / Ф. Мохаммадсадеги, В. С. Чигрин, С. В. Епифанов // Вестник НТУ «ХПИ», Серия: Новые решения в современных технологиях. - Харьков: НТУ «ХПИ». - 2016. - № 12 (1184). - С. 62-70. doi:10.20998/2413-4295.2016.12.09.

Будь ласка посилайтесь на ию статтю наступним чином:

Мохаммадсадегі, Ф. Вдосконалення методів виявлення нестійких режимів роботи осьових компресорів 3 використанням аналізу вібрацій / Ф. Мохаммадсадегі, В. С. Чигрин, С. В. Єпіфанов // Вісник НTУ «XПI», Серія: Нові рімення в сучасних технологіях. - Харків: НТУ «ХПІ». - 2016. - № 12 (1184). - С. 62-70.- doi:10.20998/2413-4295.2016.12.09. АНОТАЦІЯ Подано результати чисельного моделювання $і$ експериментальних досліджень динаміки зменшення газодинамічної стійкості ступіня осьового компресора. Виконано дослідження з визначення інформативних критеріїв виявлення передпомпажного режиму. Показано, що гармоніка зриву, щэо обертається, є стійкою, значно виділяється на фоні шумів, це дозволяє використати ї для діагностування зриву, щэо обертається, як передвісника помпажу. Приведено уточнену залежність для визначення частоти зриву, що обертається. Показано, що для виявлення обертового зриву можливе використання параметрів вібрачії, які зареєстровані на корпусі компресора. Запропоновано алгоритм виявлення передпомпажного стану компресора за рівнем вібрацій корпусу компресора для розробки автоматичних систем попередження помпажу на етапі його зародження.

Ключові слова: осьовий компресор, обертовий зрив, помпаж, вібросигнал, медіанна фільтрачія, смуговий фільтр 